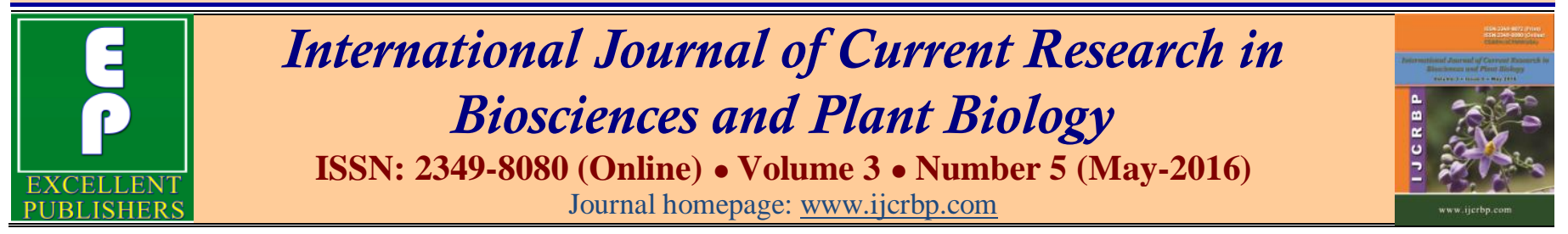

Original Research Article

doi: http://dx.doi.org/10.20546/ijcrbp.2016.305.020

\title{
Preparation and Characterization of Some New Schiff Bases Compounds with the Study of Biological Effectiveness
}

\author{
Natiq G. Ahmed and Hussein Y. Al-Hashimi* \\ Department of Chemistry, College of Education for Pure Science, University of Mosul, Mosul, Iraq \\ *Corresponding author.
}

\begin{abstract}
A bstract
A new series of Schiff bases compounds that contains a set of one or more azomethine groups through the reactance compounds (3-Morpholino-1-(3-nitrophenyl)-3-(4nitrophenyl) propan-1-one, Terephthalaldehyde, Benzylidene acetophenone) with different aromatic amines (2-Aminobenzothiazole, 4-Bromo-2-methylaniline, 5-(4methoxyphenyl)-1,3,4-thiadiazol-2-amine, 4-amino-N-(5-methyl isoxazol-3-yl) benzenesulfonamide, 2-Aminoanthracene-9,10-dione, 4-(phenyldiazenyl) aniline, 5-(2chlorophenyl)-1,3,4-thiadiazol-2-amine, Melamine, P-Phenylenediamine) using glacial acetic acid as a catalyst agent (1-10). The synthesized compounds were identified using physical and spectral methods (melting points, colour change, Thin Layer Chromatography, infrared spectra, ultraviolet spectra and nuclear magnetic resonance spectra) and biological effectiveness has also been measured for some of the prepared compounds against the growth of bacteria, Staphylococcus aureus, Escherichia coli and Pseudomonas aeruginosa. Compounds [1, 4, 7, 8 and 10] showed moderate antibacterial activity (inhibition zone 11-20 mm) on Staphylococcus aureus.
\end{abstract}

\section{Introduction}

Schiff's bases are an important class of organic compounds. They were first reported by Hugo Schiff in 1864. Schiff's bases are condensation products of primary amines with carbonyl compounds. The common structural feature of these compounds is the azomethine group with the general formula RHC $=\mathrm{N}-\mathrm{R} 1$, where $\mathrm{R}$ and R1 are alkyl, aryl, cycloalkyl or heterocyclic groups (Arulmurugan et al., 2010). Schiff's bases have also been shown to exhibit a broad range of biological activities, including antifungal, antibacterial, antimalarial, antiproliferative, antiinflammatory, antiviral, and antipyretic properties (Przybylski et al., 2009). In the present study, new Schiff bases compounds were synthesized adopting different schemes and the resultant compounds were characterized and tested for biological effectiveness by means of antibacterial activity assay.

\section{Materials and methods}

All reagents and chemicals were from BHD and SigmaAldrich companies and used without further purification, Melting points were measured using hot stage Gallen Kamp melting point apparatus and were uncorrected (Maximum temperature $240^{\circ} \mathrm{C}$ ), The Infra red spectra (FT-IR) in the range (400-4000) $\mathrm{cm}^{-1}$ were recorded using KBr disk on Shimadzu FT-IR-8300 spectrophotometer (Japan) in Ibn Sina State Company (ISSC) and College of Education Ibn-Al-Haitham - University of Baghdad - Iraq, UV/Vis spectra were recorded on UV-Cary-100 spectrophotometers in (ISSC), ${ }^{1} \mathrm{H}-\mathrm{NMR}$ spectra were recorded on a BRUKER-400 $\mathrm{MHz}$ operating with tetra methyl silane as internal standard in $\mathrm{DMSO}-\mathrm{d}_{6}$ as a solvent, measurements were made at Isfahan UniversityIran, Thin layer Chromatography (TLC) was carried out by using alumina plates percolated with silica-gel, 
supplied by Merck. Spots were detected with iodine vapor. The biological activity was performed by Biology Department, College of Science, Baghdad University. Some compounds prepared in the present study have been tested (Murray et al., 2016; Tortora et al., 2010) against the growth of bacteria, Staphylococcus aureus, Escherichia coli and Pseudomonas aeruginosa. The biological activity of compounds was determined by measuring the diameter of the empty region around the well (Inhibition zone).

The synthesis of the ketonic compound [3-Morpholino1-(3-nitrophenyl)-3-(4-nitrophenyl)propan-1-one] were listed in the literature (Ahmed and Ridha, 2015).

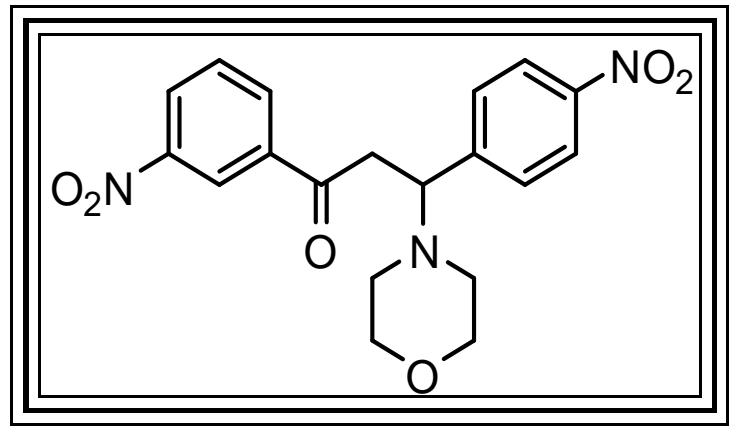

\begin{tabular}{l|l|l|l|l|l|} 
m.p. ${ }^{\circ} \mathrm{C}$ & $64-66$ & Colour & Off white (Karimi) & Yield \% & 77
\end{tabular}

Synthesis of Schiff bases compounds (1-10) (Hussain et al., 2014; Lakum et al., 2014; Al-Mosawi, 2014)

Schiff bases were prepared by reaction $(0.0025 \mathrm{~mole})$ of compound [3-Morpholino-1-(3-nitrophenyl)-3-(4-nitro- phenyl) propan-1-one] or Chalcone) Benzylideneacetophenones (dissolved in $(20 \mathrm{ml})$ of absolute ethanol. Then few drops of glacial acetic acid were added with stirring and then added to the reaction mixture $(0.0025$ mole) of different aromatic amines [2Aminobenzothiazole, 4-Bromo-2-methylaniline, 5-(4methoxyphenyl)-1,3,4-thiadiazol-2-amine, 4-amino-N-(5methyl isoxazol-3-yl) benzenesulfonamide, 2Aminoanthracene-9,10-dione,4-(phenyldiazenyl) aniline and 5-(2-chlorophenyl)-1,3,4-thiadiazol-2-amine] dissolved in $(20 \mathrm{ml})$ of absolute ethanol with stirring, and then the mixture was refluxed for period of time with follow-up by TLC. At the end of the reaction, solution was left at room temperature to cool down. Then the solvent was evaporated to obtain the precipitate which was recrystallized by absolute ethanol. The schemes for the synthesis of Schiff bases are provided in Schemes 1, 2 and 3. Physical properties and reaction time are listed in Table 1.

Note 1: The preparation of compound (7) the same method above except the use $(0.0025 \mathrm{~mole})$ of the Terephthalaldehyde with $(0.005 \mathrm{~mole})$ of 4 -amino- $\mathrm{N}-(5$ methyl isoxazol-3-yl) benzenesulfonamide.

Note 2: The preparation of compound (9) the same method above except the use $(0.005 \mathrm{~mole})$ of the Benzylideneacetophenones with $(0.0025$ mole $)$ of PPhenylenediamine.

Note 3: The preparation of compound (10) the same method above except the use $(0.0075$ mole) of the Benzylideneacetophenones with $(0.0025 \mathrm{~mole})$ of Melamine.

Table 1. Some physical properties of the compounds (1-10).

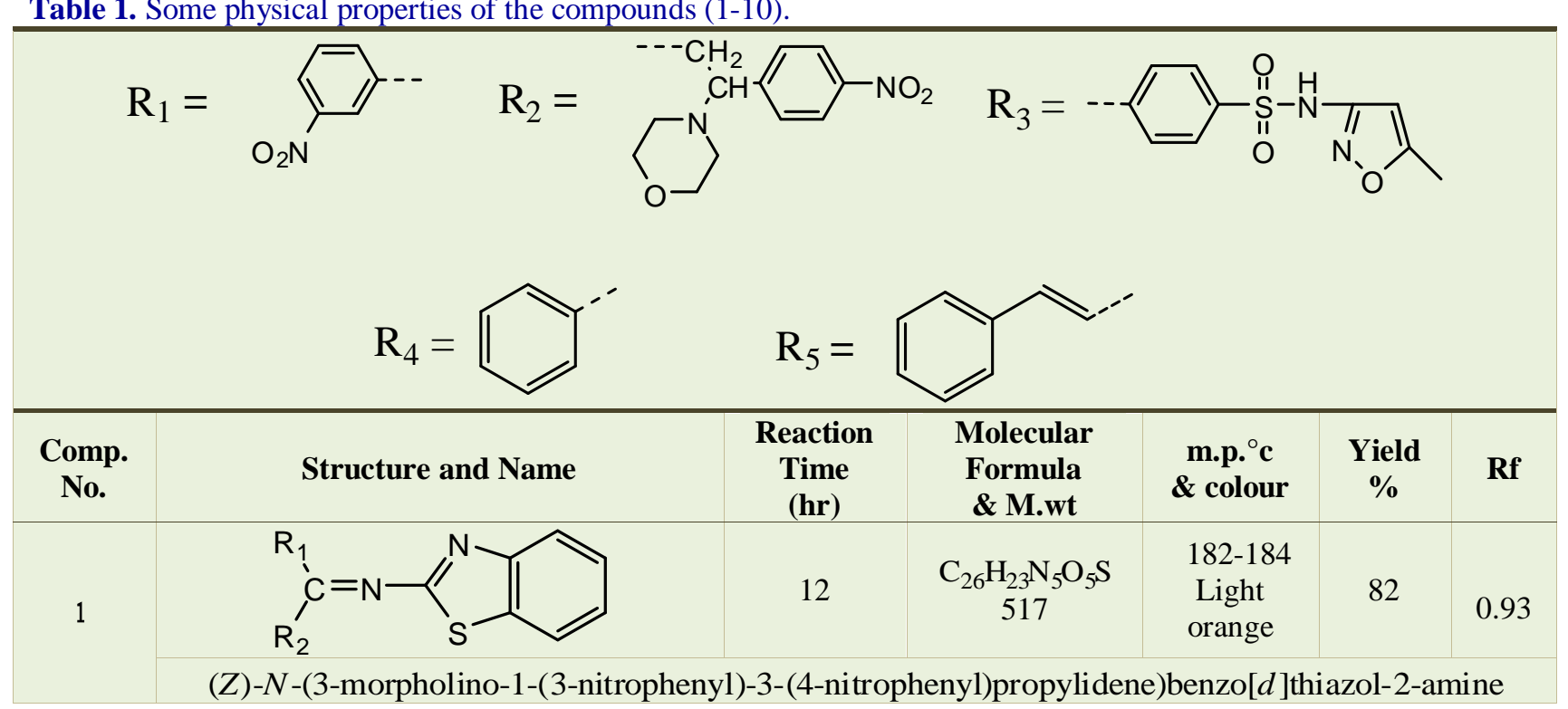


2<smiles>[R]C([R])=Nc1ccc(Br)cc1C</smiles>

18

$$
\underset{553}{\mathrm{C}_{26} \mathrm{H}_{25} \mathrm{BrN}_{4} \mathrm{O}_{5}}
$$

123-125

Yellow
92

0.80

(Z)-4-bromo-2-methyl- $N$-(3-morpholino-1-(3-nitrophenyl)-3-(4-nitrophenyl)propylidene)aniline

3<smiles>[R]C([R])=Nc1nnc(-c2ccc(OC)cc2)s1</smiles>

8

$$
\begin{array}{c|c}
\mathrm{C}_{28} \mathrm{H}_{26} \mathrm{~N}_{6} \mathrm{O}_{6} \mathrm{~S} & 207-209 \\
574 & \text { Orange }
\end{array}
$$

82

0.77

(Z)-5-(4-methoxyphenyl)- $N$-(3-morpholino-1-(3-nitrophenyl)-3-(4-nitrophenyl)propylidene)-1,3,4thiadiazol-2-amine<smiles>[R]C([R])=Nc1ccc(S(=O)(=O)Nc2cc(C)on2)cc1</smiles>

10

$$
\begin{array}{c|c}
\mathrm{C}_{29} \mathrm{H}_{28} \mathrm{~N}_{6} \mathrm{O}_{8} \mathrm{~S} & 137-139 \\
620 & \text { Orange }
\end{array}
$$

(Z)-N-(5-methylisoxazol-3-yl)-4-(3-morpholino-1-(3-nitrophenyl)-3-(4nitrophenyl)propylideneamino)benzenesulf onamide

5<smiles>[R]C([R])=Nc1ccc2c(c1)C(=O)c1ccccc1C2=O</smiles>

13

$$
\begin{gathered}
\mathrm{C}_{33} \mathrm{H}_{26} \mathrm{~N}_{4} \mathrm{O}_{7} \\
590
\end{gathered}
$$

(Z)-2-(3-morpholino-1-(3-nitrophenyl)-3-(4-nitrophenyl)propylideneamino) anthracene-9,10-dione

6

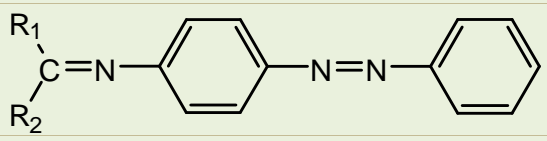

6
$168-171$

Black

(NZ)- $N$-(3-morpholino-1-(3-nitrophenyl)-3-(4-nitrophenyl)propylidene)-4-(phenyldiazenyl)aniline

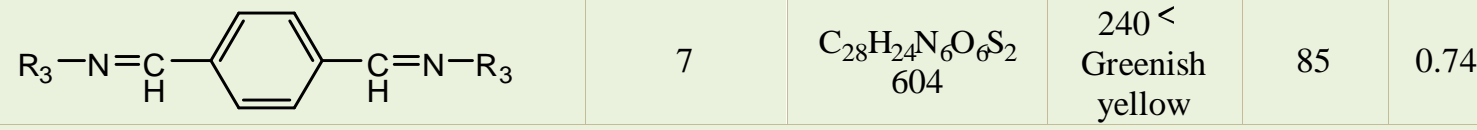

4,4'-(1E,1'Z)-(1,4-phenylenebis(methan-1-yl-1-ylidene))bis(azan-1-yl-1-ylidene)bis( $N$-(5-methylisoxazol3-yl)benzenesulfonamide)<smiles>[R3]C([R3])=Nc1nnc(-c2ccccc2Cl)s1</smiles>

9

$$
\underset{401}{\mathrm{C}_{23} \mathrm{H}_{16} \mathrm{ClN}_{3} \mathrm{~S}}
$$

$138-140$

Reddish brown
8

93

(Z)-5-(2-chlorophenyl)- $N$-((E)-1,3-diphenylallylidene)-1,3,4-thiadiazol-2-amine<smiles>[R3]C([R5])=Nc1ccc(N=C([R5])[R5])cc1</smiles>

9

8
$117-119$

Black

10

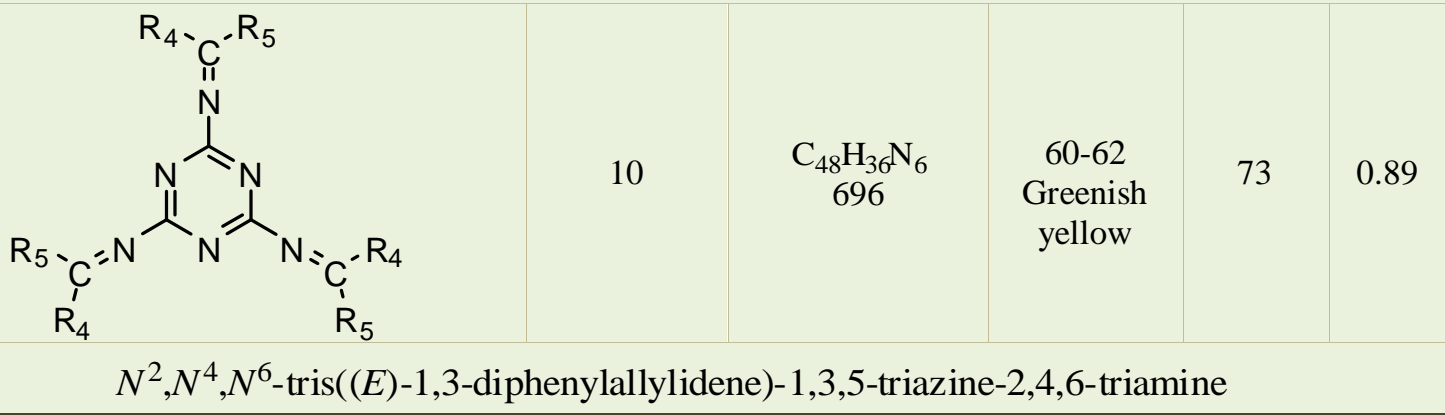




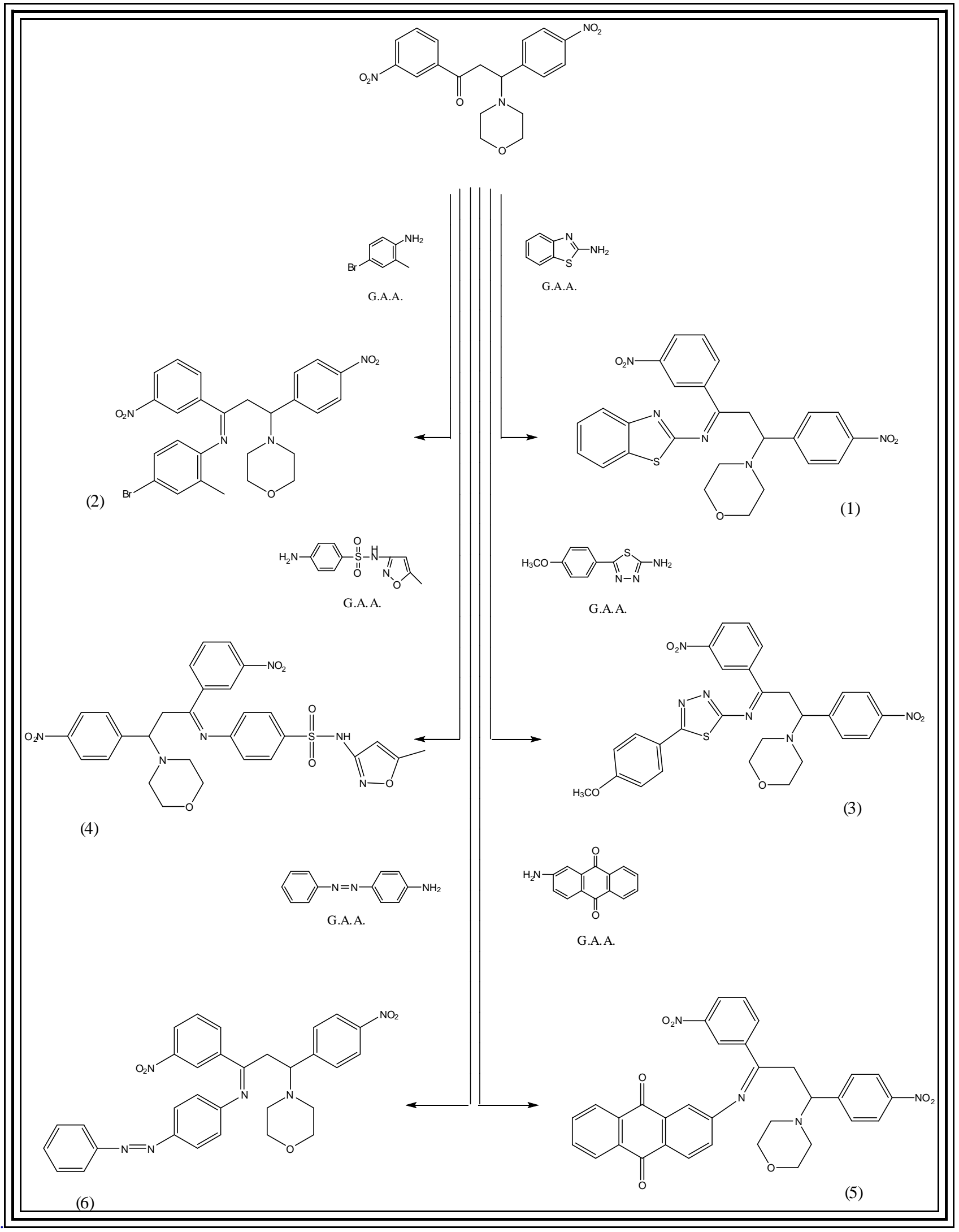

Scheme 1: The preparation of a number of new Schiff bases.

Natiq G. Ahmed and Hussein Y. Al-Hashimi (2016) / Preparation and Characterization of Some New Schiff Bases Compounds with the Study of Biological Effectiveness 


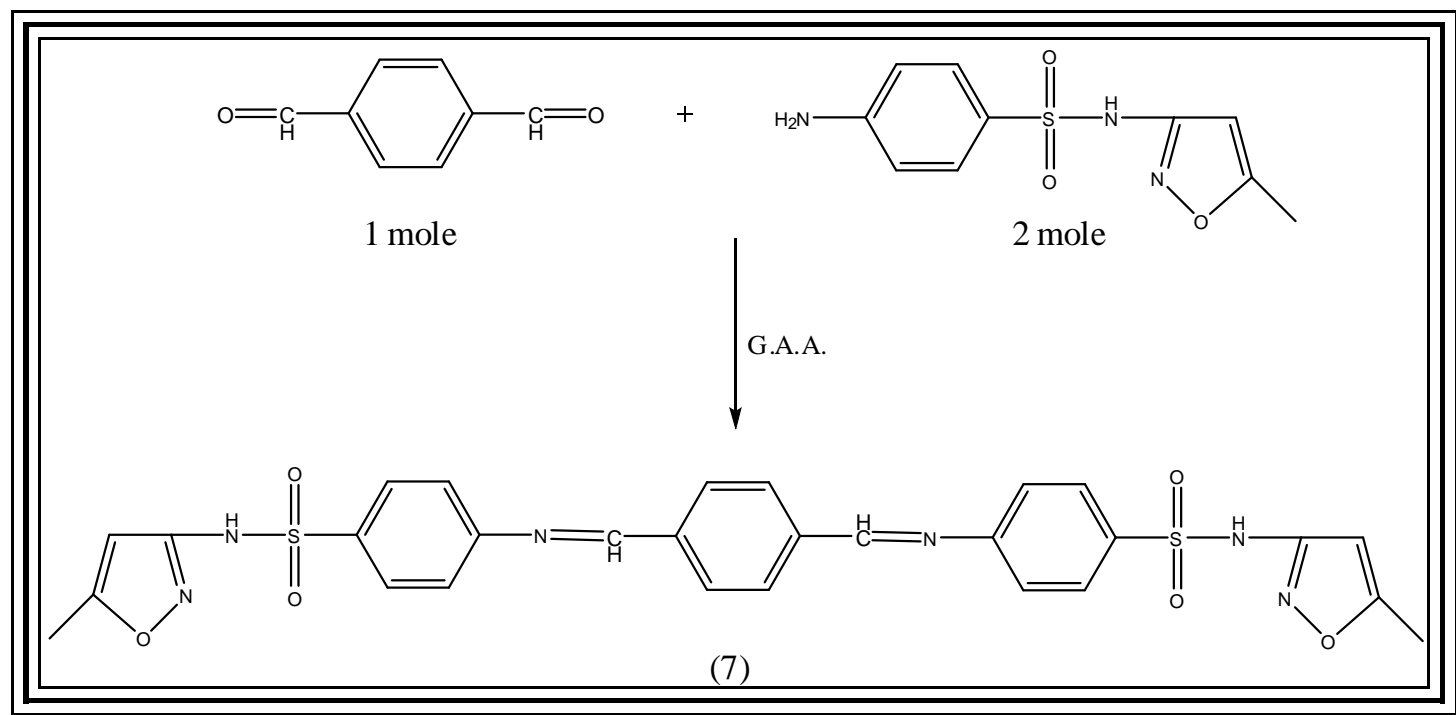

Scheme 2: Preparation of double Schiff base compounds.

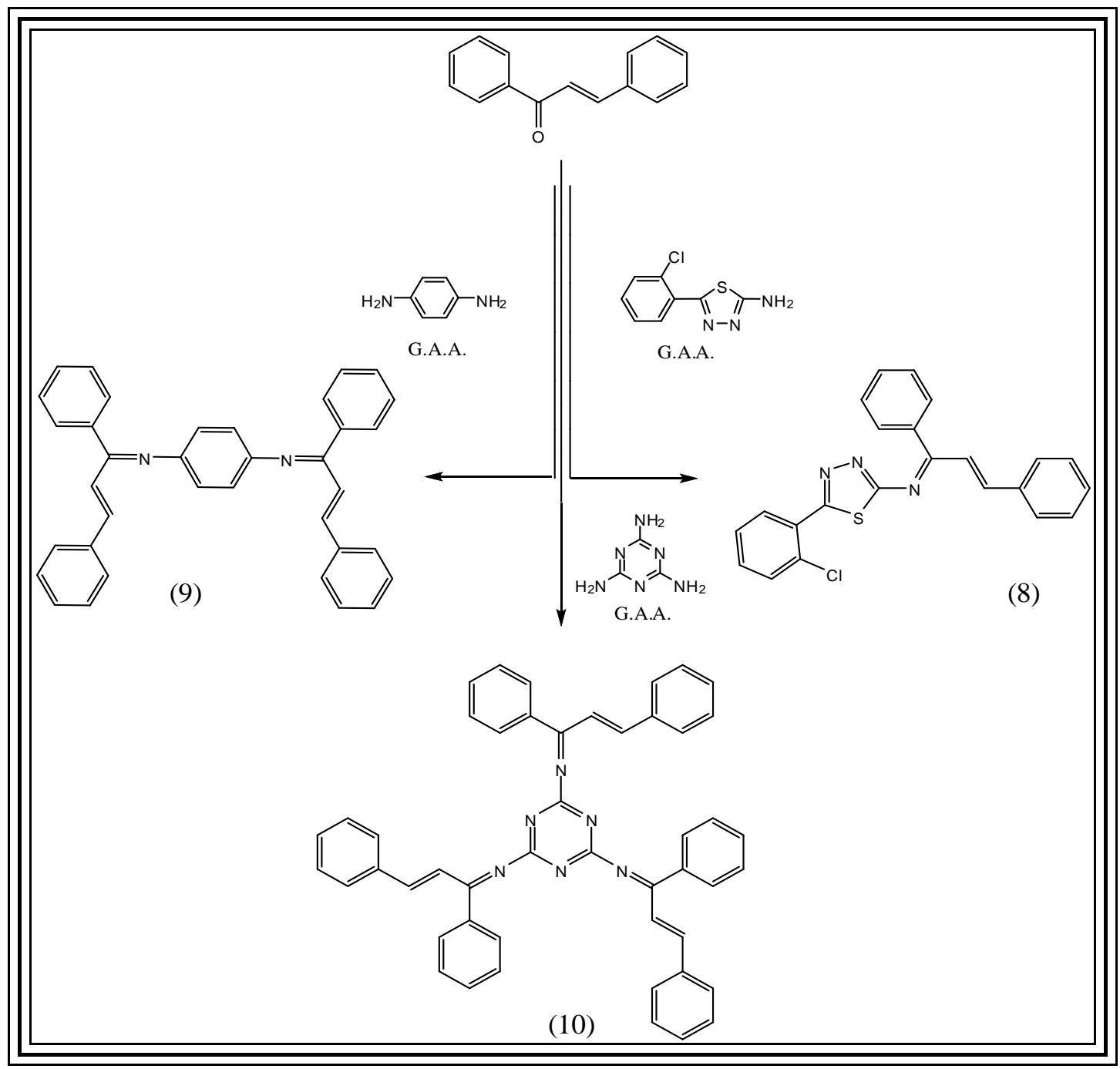

Scheme 3: The preparation of a number of multi-Schiff bases. 


\section{Results and discussion}

Ten new Schiff bases were synthesized from the reaction of [3-Morpholino-1-(3-nitrophenyl)-3-(4nitrophenyl) propan-1-one, Benzylideneacetophenones or Terephthalaldehyde] with different aromatic amines in absolute ethanol and in the catalytic amount of glacial acetic acid. The FT-IR spectra of Schiff bases compounds (1-7) showed the disappearance of peak of carbonyl group and the new peaks which appeared at
1599-1670 $\mathrm{v} \mathrm{cm}^{-1}$ which is attributed to the new azomethine $(\mathrm{C}=\mathrm{N})$ group (Mahmoud et al., 2013; Wadher et al., 2009). As shown in Fig. 2, the UV/VIS Spectrum gave absorption peaks at different wave lengths $(210-294 \mathrm{~nm})$ due to $\left(\pi \rightarrow \pi^{*}\right)$ and different wave lengths (321-354 nm) due to $\left(\mathrm{n} \rightarrow \pi^{*}\right)$ (in DMSO). All the spectral data for compounds are listed in Table 2. The NMR spectrum (Shanmugapriya et al., 2012) of the compound (2) gave bands of 7.10$8.70 \boldsymbol{\delta}, \mathrm{m}, \mathrm{Ar}-\mathrm{H}$.

Table 2. Some spectral properties of the compounds (1-7).

\begin{tabular}{|c|c|c|c|c|c|c|c|c|}
\hline \multirow{2}{*}{$\begin{array}{l}\text { Comp. } \\
\text { No. }\end{array}$} & \multicolumn{7}{|c|}{ IR $(\mathrm{KBr}), v\left(\mathrm{~cm}^{-1}\right)$} & \multirow{2}{*}{$\begin{array}{l}\text { U.V. } \\
\lambda \text { max, nm }\end{array}$} \\
\hline & Ar C-H & R C-H & C=N Exo & $\mathrm{C}-\mathrm{N}-\mathrm{C}$ & C-O-C & -NO2 & Others & \\
\hline \multirow[t]{2}{*}{1} & 3078 & 2945 & 1612 & 1217 & 1012 & 1344 & $\mathrm{C}=\mathrm{N} 1593$ & 340 \\
\hline & 3064 & $\begin{array}{l}2872 \\
2854\end{array}$ & & & 1109 & & & 210 \\
\hline \multirow[t]{2}{*}{2} & 3095 & 2989 & 1610 & 1213 & 1084 & 1344 & C-Br 619 & 354 \\
\hline & 3047 & $\begin{array}{l}2949 \\
2891\end{array}$ & & & 1111 & & & 271 \\
\hline \multirow[t]{2}{*}{3} & 3082 & 2962 & 1599 & 1251 & 1026 & 1338 & $\mathbf{C}=\mathbf{N} 1583$ & 350 \\
\hline & & $\begin{array}{l}2904 \\
2837\end{array}$ & & & 1105 & & & 264 \\
\hline \multirow[t]{3}{*}{4} & 3091 & 2943 & 1610 & 1267 & 1008 & 1342 & $\mathbf{C}=\mathbf{N} 1583$ & 353 \\
\hline & 3059 & 2862 & & & 1089 & & $C=C 1595$ & 283 \\
\hline & 3034 & 2843 & & & & & N-H 3292 & \\
\hline \multirow[t]{2}{*}{5} & 3075 & 2925 & 1670 & 1247 & 1078 & 1340 & $C=O 1691$ & 324 \\
\hline & 3028 & 2836 & & & 1109 & & & 294 \\
\hline \multirow[t]{3}{*}{6} & 3055 & 2991 & 1608 & 1211 & 1035 & 1342 & $\mathbf{N}=\mathbf{N} 1593$ & ---- \\
\hline & 3018 & 2906 & & & 1084 & & & \\
\hline & & 2868 & & & & & & \\
\hline \multirow[t]{2}{*}{7} & 3070 & 2995 & 1616 & 1267 & 1030 & ---- & $\mathbf{C}=\mathbf{N} 1583$ & 321 \\
\hline & & 2879 & & & 1087 & & N-H 3308 & 258 \\
\hline
\end{tabular}

The FT-IR spectra of Schiff bases compounds (8-10) showed the disappearance of bands of carbonyl group and the new bands appeared at $\left(1660-1664 \mathrm{v} \mathrm{cm}^{-1}\right)$ is attributed to the new azomethine $(\mathrm{C}=\mathrm{N})$ group (Jadhav et al., 2015). As shown in Figs. 3 and 4, the UV/VIS
Spectrum gave absorption bands at different wave lengths $(257-293 \mathrm{~nm})$ due to $\left(\pi \rightarrow \pi^{*}\right)$ and different wave lengths $(309-370 \mathrm{~nm})$ due to $\left(\mathrm{n} \rightarrow \pi^{*}\right)$ (in DMSO) (Guofeng et al., 2003). All the spectral data for compounds are listed in Table 3.

Table 3. Some spectral properties of the compounds (8-10).

\begin{tabular}{|c|c|c|c|c|c|c|}
\hline \multirow[t]{2}{*}{ Comp. No. } & \multicolumn{5}{|c|}{ IR (KBr), v $\left(\mathrm{cm}^{-1}\right)$} & \multirow{2}{*}{$\begin{array}{l}\text { U.V. } \\
\lambda \max , \mathrm{nm}\end{array}$} \\
\hline & Ar C-H & R C-H & $\mathrm{C}=\mathrm{N}$ Exo & $\mathrm{C}=\mathrm{C}$ Conj. & Others & \\
\hline 8 & 3055 & $\begin{array}{l}2963 \\
2909\end{array}$ & 1660 & 1599 & $\begin{array}{l}\text { C=N } 1573 \\
\text { C-Cl } 744\end{array}$ & $\begin{array}{l}313 \\
257\end{array}$ \\
\hline 9 & 3057 & $\begin{array}{l}2968 \\
2895 \\
2856\end{array}$ & 1664 & 1595 & ---- & $\begin{array}{l}370 \\
309 \\
293\end{array}$ \\
\hline 10 & $\begin{array}{l}3086 \\
3057\end{array}$ & $\begin{array}{l}2931 \\
2802\end{array}$ & 1660 & 1699 & $\mathbf{C}=\mathbf{N} 1571$ & $\begin{array}{l}321 \\
274\end{array}$ \\
\hline
\end{tabular}


New Schiff bases compounds showed slightly active to moderately active against the growth of bacteria, Staphylococcus aureus, Escherichia coli and Pseudomonas aeruginosa measured in terms of zone of inhibition. The results of preliminary screening tests are listed in Table 4. The compound 1 showed moderate activity against Staphylococcus aureus and Escherichia coli, whereas the compounds 4, 8 and 10 showed moderate activity against Staphylococcus aureus and Pesudomonas aeruginosa.

Table 4. Antibacterial activities of some prepared compounds.

\begin{tabular}{llll}
\hline Comp. No. & $\begin{array}{l}\text { Staphylococcus aureus } \\
\text { G+ve }\end{array}$ & $\begin{array}{l}\text { Escherichia coli } \\
\text { G-ve }\end{array}$ & $\begin{array}{l}\text { Pseudomonas aeruginosa } \\
\text { G-ve }\end{array}$ \\
\hline 1 & ++ & ++ & + \\
4 & ++ & + & ++ \\
7 & ++ & + & + \\
8 & ++ & + & ++ \\
10 & ++ & + & ++ \\
\hline
\end{tabular}

Key to symbols: Highly active $=+++($ inhibition zone $>20 \mathrm{~mm}$ ); Moderately active $=++$ (inhibition zone $11-20 \mathrm{~mm}$ ); Slightly active $=+($ inhibition zone $5-10 \mathrm{~mm})$.

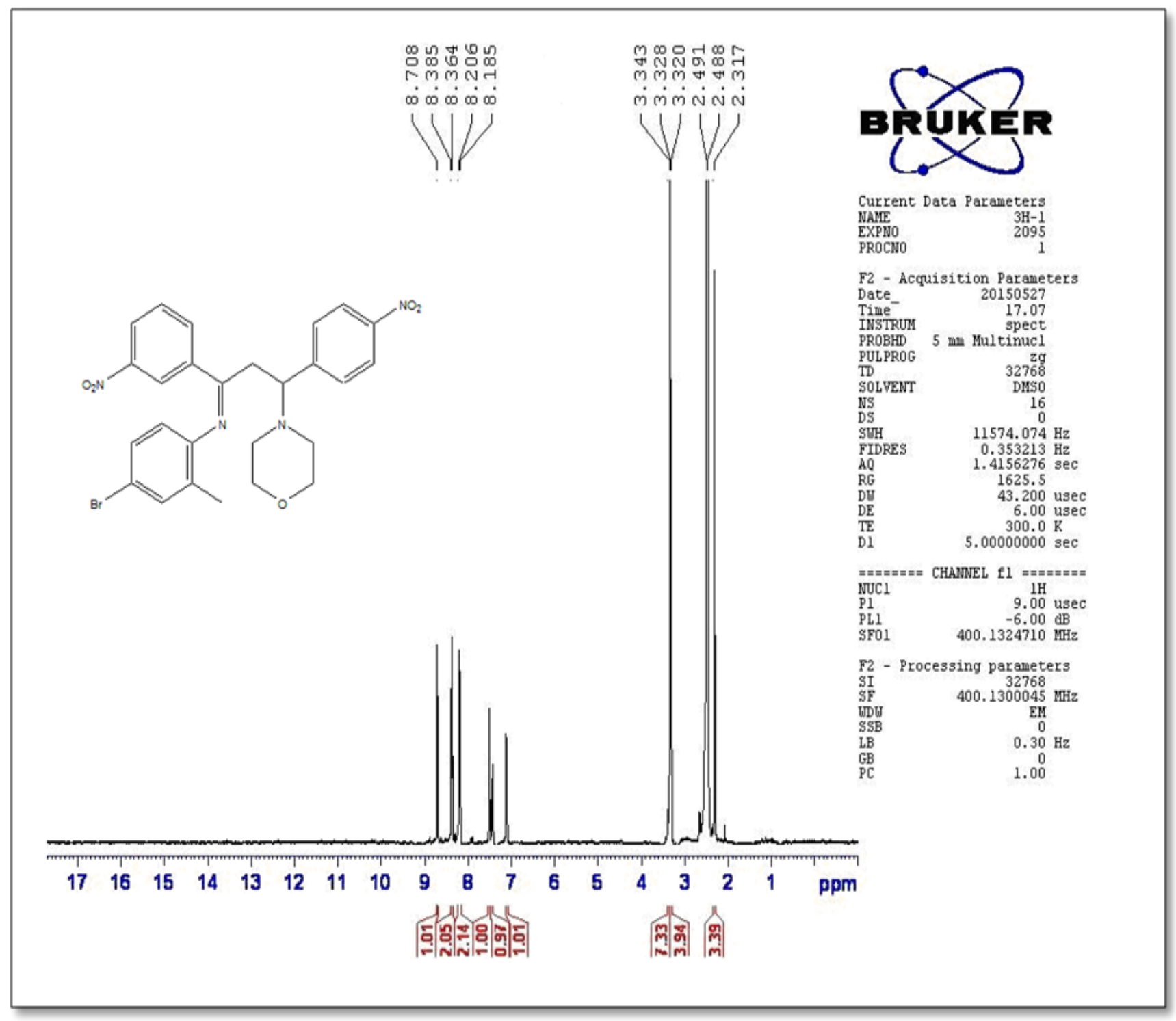

Fig. 1: ${ }^{1} \mathrm{H}-\mathrm{NMR}$ spectrum of compound [2] 


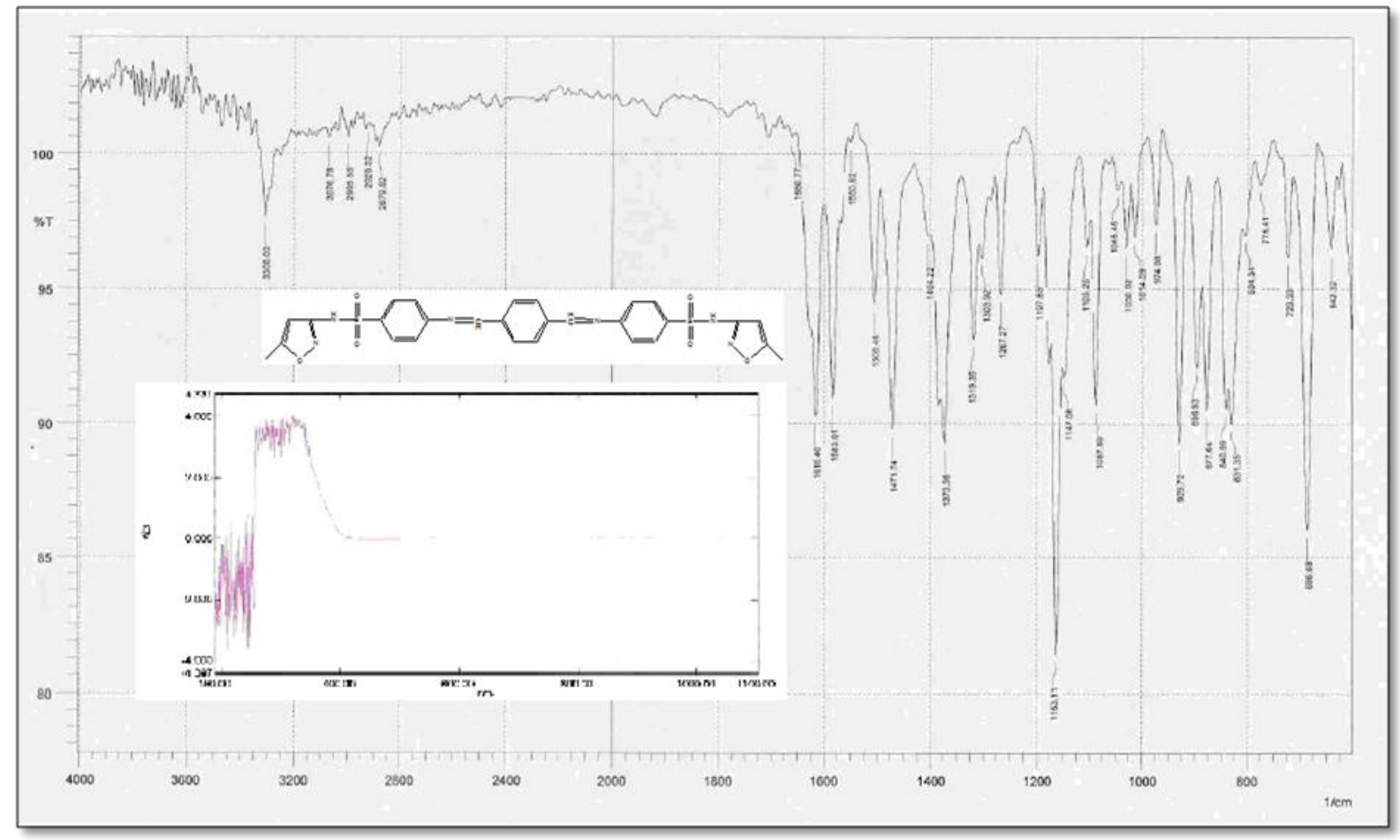

Fig. 2: FT-IR spectrum and UV spectrum of compound [7].

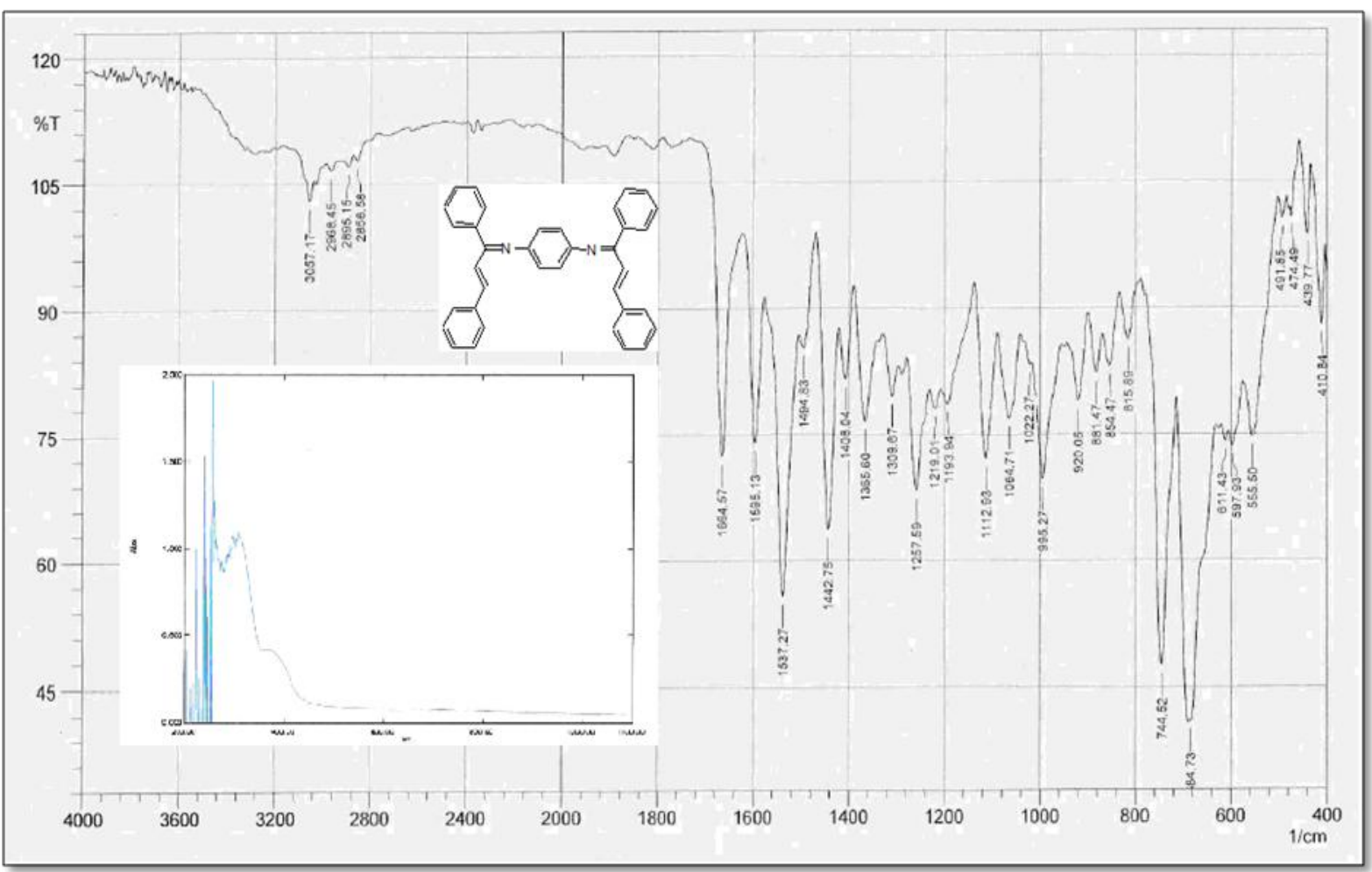

Fig. 3: FT-IR spectrum and UV spectrum of compound [9]. 


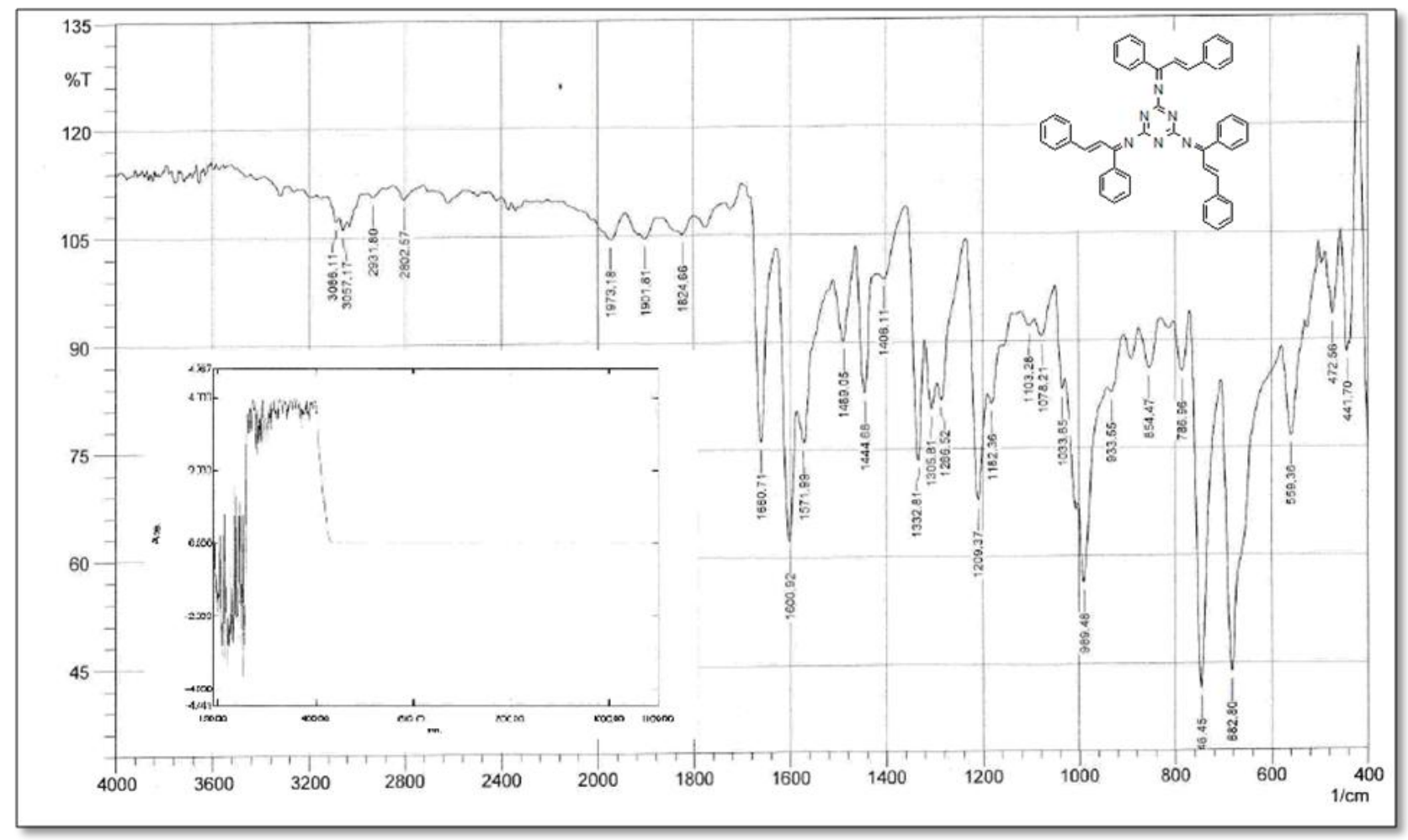

Fig. 4: FT-IR spectrum and UV spectrum of compound [10].

\section{Conclusion}

Ten new Schiff bases compounds were successfully synthesized and characterized and among which five compounds were tested for their biological activity in terms of antibacterial activity.

1. Compounds [1, 4, 7, 8 and 10] showed moderately active on Staphylococcus aureus.

2. Compound [1] showed moderately active and compounds [4, 7, 8 and 10] showed slightly active on Escherichia coli.

3. Compounds [4, 8 and 10] showed moderately active and compounds [1 and 7] showed slightly active on Pseudomonas aeruginosa.

\section{Conflict of interest statement}

Authors declare that they have no conflict of interest.

\section{References}

Ahmed, N. G., Ridha, H. Y., 2015. Preparation and characterization of some new oxazepine compounds: Eur. Chem. Bull. pp.1-19.
Al-Mosawi, S. K., 2014. Synthesis and characterization of heterocyclic Schiff base, thaizolidinone and chalcone as antibacterial agents. Res. J. Pharmaceut. Biol. Chem. Sci. 5(6), 411-417.

Arulmurugan, S., Kavitha, P. H., Venkatraman, R. P., 2010. Biological activities of Schiff base and its complexes: A review. Rasayan J. Chem. 3(3), 385-410.

Guofeng, C., Jitai, L., Huiyum, D., Tongshuang, L., 2003. Keylab of Analytical Science and Technology, China.

Hussain, Z., Yousif, E., Ahmed, A., Altaie, A., 2014. Synthesis and characterization of Schiff's bases of sulfamethoxazole. Org. Med. Chem. Lett. 4(1), 1-4.

Jadhav, J. S., Bodawar, K. R., Panchal, G. V., 2015. Synthesis and characterization of 1,3-diphenylallylidene benzothiazol-2-amine derivatives. Int. J. ChemTech Res. 7(6), 2809-2813.

Lakum, H. P., Shah, D. R., Chikhalia, K. H., 2014. Novel striazinyl Schiff base/chalcone congeners: Rational, synthesis, antimicrobial and anti-TB evaluation. Int. Lett. Chem. Phys. Astron. 38, 56-73.

Mahmoud, M. J., Jassim, I. K., Mahmoud, M. A., 2013. Synthesis and characterization of five, seven heterocyclic membered rings. Baghdad Sci. J. 10(3), 803-817.

Murray, P.R., Rosenthal, K. S., Pfaller, M. A., 2016. Medical Microbiology. $8^{\text {th }}$ Edn. Elsevier, PA.

Przybylski, P., Huczyński, A., Pyta, K., Brzezinski, B., Bartl, F., 2009. Biological properties of Schiff bases and azo derivatives of phenol. Curr. Org. Chem. 13, 124-148. 
Shanmugapriya, M., Jameel, A. A., Padusha, M. S., 2012. Synthesis, characterisation and antimicrobial activities of salicylaldehyde derivatives. Int. J. ChemTech Res. 4(1), 12-15.

Tortora, G. J., Funke, B. R., Case, C. L., 2010. Microbiology An Itroduction. $10^{\text {th }}$ Edn. Pearson Benjamin Cummings, San Francisco, CA.
Wadher, S. J., Puranik, M. P., Karande, N. A., Yeole, P. G., 2009. Synthesis and biological evaluation of Schiff base of dapsone and their derivative as antimicrobial agents. Int. J. PharmTech Res. 1(1), 22-33.

\section{How to cite this article:}

Ahmed, N. G., Al-Hashimi, H. Y., 2016. Preparation and characterization of some new Schiff bases compounds with the study of biological effectiveness. Int. J. Curr. Res. Biosci. Plant Biol. 3(5), 127136. doi: http://dx.doi.org/10.20546/ijcrbp.2016.305.020 